This article is (c) Emerald Group Publishing and permission has been granted for this version to appear here (https://dspace.lib.cranfield.ac.uk/index.jsp). Emerald does not grant permission for this article to be further copied/distributed or hosted elsewhere without the express permission from Emerald Group Publishing Limited.

www.emeraldinsight.com

\title{
Boundaryless Career Drivers - Exploring Macro-Contextual Factors in Location Decisions
}

\begin{abstract}
Purpose: This paper explores what attracts individuals to live in a South East Asian city. It uses a boundaryless career approach that is interested in how people cross traditional career boundaries, including those related to country and location barriers. Going beyond an individual and organizational view, a more extensive model of location decisions is developed that incorporates broad macro-factor career drivers.
\end{abstract}

Design/methodology/approach: A large scale qualitative study explored individual, organizational, political, economic, socio-cultural, technological, ecological, legal, natural and general drivers to live in the city. We interviewed 43 individuals who had moved to the city from abroad, were born in the city and still lived there or who were born in the city but had moved to another foreign city.

Findings: Many macro-contextual factors - i.e. day-to-day regulatory stability and transparency, economic growth, friendliness and meritocracy, safety and a good, clean environment - were seen as attractive by all three groups. People who had left the city raised some specific criticism regarding the vibrancy, freedom and creativity of thought.

Research limitations/implications: The study focused on highly skilled individuals who most often had experience in living in different cities to get more reflective views. However, this restricted the generalizability. The findings nuance the understanding of boundaryless careers.

Practical implications: The research expands the normally used attraction factors and develops a broader framework of city attractiveness drivers. The emerging picture can be used by the city administration to manage its global attractiveness while increasing nonregulatory 'stickiness' to retain talent. 
Social implications: The research has social implications with respect to cross-border boundaryless careers and talent acquisition, management and retention strategies.

Originality/value: Our research expands the macro-contextual discussion and goes beyond the dominant focus on individuals and organizations when investigating boundaryless careers. The study uses an innovative method as it does not only interview foreign expatriates but also two further, more neglected groups: local citizens and individuals who had left the city. It develops an extended model of boundaryless location drivers and develops some exemplary propositions.

Keywords: Boundaryless Careers, Global Careers, City Attractiveness, International Mobility, Decision to live abroad 


\section{Boundaryless Career Drivers - Exploring Macro-Contextual Factors in Location Decisions}

\section{INTRODUCTION}

Modern career paradigms have been applied to research a wide range of phenomena in global careers. Most often, studies have investigated individual careerists' personalities, attitudes, behaviours and career outcomes (Sullivan and Baruch, 2009). Where careers were investigated within a context, the social networks of individuals, their cultural embeddedness or their organizational circumstances have predominantly been explored (Gunz et al., 2007). The boundaryless career is one of the most prevalent theoretical approaches to explore international mobility (Shaffer et al., 2012). However, too little research has been conducted to understand macro-context factors such as political and economic conditions, societal and industry differences as well as organizational staffing policies that influence physical and psychological willingness to work abroad (Ng et al., 2007; Sullivan and Arthur, 2006). Al Ariss et al., (2012:95) argue that international mobility research neglects contextualization and rarely analyses from a multi-level relational perspective. Research that explores these interrelated factors and their impact on boundaryless careers is hitherto relatively neglected.

One way to explore contextualization within global careers is to focus on one or a few particular locations and to investigate the broad macro-context including wider location factors (Al Ariss et al., 2012). However, our knowledge about the attractiveness of working in specific locations and individuals' careers is severely underdeveloped from both the careers literature (for exceptions see Haslberger and Zehetner (2008) on Vienna and Dickmann and Mills (2010) on London) and/or human geography (Fotheringham et al., 2000). The complex relationship of individual, organizational and broader macro-factors on global careerists' choices on crossing national boundaries to work in a particular city needs to be explored. A better exploration of the broad location context can nuance our understanding of boundaryless career decisions and expatriation drivers.

This paper attempts to fill this gap by concentrating on a South East Asian city. It will argue that there are a range of features in the South East Asian city that can be attractive to individual careerists, be they foreign or domestic citizens. Amongst these are a stable political environment and business-friendly policies that have made the city attractive for 
multinational corporations to locate and generate employment. The economy is characterized by high growth rates and favourable corporate tax rates. It is regarded as a secure city with low crime rates. Moreover, its education system provides good secondary and tertiary education. Living and working in the South East Asian city might, therefore, be highly attractive to both expatriates and locals. However, little is known regarding the city's attractiveness evaluation in the minds of individuals, the psychological and physical attachment of individuals to the city or their career patterns.

Our research poses the question 'What are the key factors that influence the decisions of individuals to live in a particular South East Asian city?' The contributions of this paper are the following. Empirically it investigates city attractiveness, a hitherto relatively neglected field and explicates insights from a South East Asian city. Using three groups - highly skilled expatriates having moved to the city, highly skilled locals who stayed in the city and highly skilled locals who have moved to New York, London, Hong Kong or Shanghai - gives a nuanced picture of city attractiveness. Theoretically, it takes up the call from Al Ariss et al., (2012) to contextualize international mobility. In addition, we analyse location choice drivers from multiple levels. Moving beyond migration this research expands their framework and adds to the expatriation and boundaryless career literature (Ng et al., 2007).

\section{LITERATURE REVIEW}

Sullivan and Baruch (2009) argue that in recent years protean and boundaryless careers have become the dominant concepts within the career field. Protean careerists (Hall, 1976; 1996), are seen as being capable of altering the shape of their careers (akin to the Greek god Proteus changing his figure) thereby reacting flexibly to a dynamic context in order to fit their capabilities to the needs of the world of work. Protean and boundaryless career elements can occur concurrently (Granrose and Baccili, 2006).

Boundaryless careers, a slight misnomer as it is clear that boundaries continue to exist (Baruch, 2004), looks at how careerists cross physical work borders such as changing organizations or moving to other countries (Sullivan and Baruch, 2009). Moreover, crossing psychological boundaries such as the consideration of downshifting or lateral job moves are also included in the concept (Sullivan and Arthur, 2006; Arthur et al., 2005). Therefore, 'traditional organizational career arrangements' are challenged by the boundaryless career 
framework (Arthur and Rousseau, 1996, p. 9). Sullivan and Baruch (2009) have compiled an in depth review of the literature.

The boundaryless career approach is one of the key theoretical approaches within global mobility (Shaffer et al., 2012, p. 1288) but can also be used to analyse within country mobility and 'bounded' careers. The literature review below first outlines global boundaryless career drivers. It will then argue that we have concentrated mostly on individual, psychological and organizational factors to the detriment of broader location factors (Tarique and Schuler, 2010; Ng et al., 2007). Then we summarise what is known about specific city location attractiveness and make the case for the need to analyse a range of macroinstitutional (Al Ariss et al., 2012) and natural-general factors.

\section{DRIVERS TO WORK ABROAD - INDIVIDUAL AND ORGANIZATIONAL FACTORS}

There is an extensive literature on the reasons why individuals may be willing to work abroad (Brookfield, 2012; Stahl et al., 2002). Key antecedents include an individual's family and social background, early experiences and personality. In terms of individual motivations, authors often distinguish key motives as, first, career and developmental considerations; second, organizational factors; third, individual interests, experiences and drives; fourth, family and partner considerations, including issues such as dual careers or influences of the extended family; as well as fifth, national and other location factors (Dickmann and Mills, 2010; Gregersen et al.,1998; Mendenhall, 2001; Richardson and Mallon, 2005; Suutari and Brewster, 2000; Tung, 1998; Stahl et al., 2002). Below, we discuss the motivations to seek and/or accept foreign work broadly. In the summary we distinguish drivers for self-initiated (SIEs) and assigned expatriates (AEs) and outline their importance.

Family and Other Social Background Factors. Norms and values acquired through family and environment, ethnicity, one's language skills, the national and cross-national relationships of oneself and one's family, the social background of the family and other influences that shape an individual's view of the world have an effect on the propensity to engage in international work and careers (Mayrhofer et al., 2004; Peiperl and Jonsen, 2007). Since moving overseas often entails a physical separation from family and friends, Tharenou (2003) demonstrated that some of the key barriers to young people exploring international 
work options were family and partner influence. The stronger the cultural and family links to one's country/city, the less likely people are to leave to work elsewhere.

Personality and Safety. Self-confidence is often seen as increasing individuals' receptivity to international careers (Sparrow et al., 2004). Bird and Osland (2004) argue that personality traits such as humility, integrity, hardiness and inquisitiveness improve the capability to work abroad. In addition, personal agency, self-efficacy and positive expectations lead to a higher willingness to work overseas (Tharenou, 2003). Safety considerations can also play a role in the decision to work abroad (Yurkiewicz and Rosen, 1995; Dickmann et al., 2008).

\section{Career and Development Considerations.}

Expatriates appreciate their international experience as an opportunity for personal and professional development and career advancement (Brett and Stroh, 1995; Stahl and Cerdin, 2004). Moreover, internationally mobile employees value the opportunity to learn unusual skills and gather foreign experiences (Tung, 1998). Considerations by individuals of their future job and the impact of foreign work on their own development and career opportunities are likely to be key considerations for company-sent internationally mobile individuals (Yan et al., 2002) and self-initiated expatriates (Jokinen et al, 2008). The job offered and related career opportunities that might arise have a strong influence on the decision to accept the foreign work (Stahl et al., 2002).

Individual Interests and Drives. Inkson et al. (1997) argue that individuals often pursue personal interests by working abroad (see also Tung, 1998). Amongst the prominent motives are the desire for adventure, travel, life change (Richardson and Mallon, 2005) and personal challenge (Stahl et al., 2002). Less frequent motivations are a general wish to live abroad, better work-life balance or personal health considerations.

Considerations of Family, Partner and Friends. There is an expanding literature on the families of internationally mobile individuals, expatriate couples and dual careers (Brett and Stroh, 1995; Harvey, 1995; Linehan and Walsh, 2000). Writers have suggested that organizations should consider both partners' willingness to relocate when taking their international resourcing decisions and to factor in dual career issues (Cerdin, 2008; Sparrow et al., 2004). While friends and family are often seen as barriers to global mobility, Richardson and Mallon (2005: 414) and Richardson (2006) suggest that in some cases family 
factors and other relationships can be an incentive to expatriation. The reasons can often be found in the broad learning experiences and the opportunities for education.

Organizational Factors. The decision to accept an overseas assignment is influenced by the likely financial impact (Yurkiewicz and Rosen, 1995). However, impact in the expatriation decision of financial considerations may vary according to the nationality of individuals. Stahl et al., (2002) found that their sample of German managers appeared to rate financial considerations as less influential compared to American research. Organizations that provide good monetary and non-monetary deals for individuals are attractive for highly talented persons.

In addition, human resource development approaches and diversity policies (Mellahi and Collings, 2010; Scullion and Collings, 2011; Vaiman and Haslberger, 2013) have an impact on the attractiveness of employers and will influence the global careers of individuals, especially those of AEs. Endogenous drivers of global talent management approaches will have an impact on the opportunities individuals gain (Tarique and Schuler, 2010). In addition, discrimination strategies and practices (Andresen et al., 2012; Al Ariss et al., 2012) can present a barrier to boundaryless global careers.

The literature identifies a large number of expatriation drivers and barriers. While research traditionally has focused on AEs (Jokinen et al., 2008) there are an increasing number of studies (Vaiman and Haslberger, 2013) exploring the motivations and experiences of SIEs. The emerging picture shows many differences between the populations. SIEs are different with respect to their educational background (Tharenou and Caulfield, 2010), their adjustment to their host location (Peltokorpi, 2008), their length of stay in the host country (Cerdin and Selmer, 2014, Tharenou, 2010; Doherty et al., 2011), their hierarchical level at work (Cerdin and Le Pargneux, 2010; Peltokorpi and Froese, 2009) and their propensity to live with the higher risk they accept when moving abroad on their own initiative (Richardson and Mallon, 2005). Especially noteworthy are the differences between AEs and SIEs with respect to their motivations to work abroad (Oberholster et al., 2013; Carr et al., 2005). Doherty et al., (2011) compare both populations directly and find that SIEs are more driven by personal interests such as a desire for adventure and a thirst to see the world and that they seek holistic life enhancing experiences (see also Biemann \& Andresen, 2010; Cerdin, 2012). It seems that the context beyond the organisation is more important to SIEs than AEs. In turn, 
AEs have stronger career and development drivers. A recent book has several in-depth discussions of these differences (Andresen et al., 2012).

\section{DRIVERS TO WORK ABROAD - LOCATION-SPECIFIC FACTORS}

Studies have normally concentrated on expatriates either from different countries (inbound to a country or organization) such as those by Stahl et al. (2002- for AEs) and Richardson and Mallon (2005 - for SIEs) or focused on a specific country of origin (outbound to various countries and organizations) such as those by Inkson and Myers (2003 - for SIEs) or Jokinen et al. (2008 - for SIEs and AEs). In addition, a systematic comparison of the drivers of local citizens to stay in their country is underdeveloped in the literature. One exception is a study by Doherty et al. (2010) which found for young EU citizens who stayed local that these evaluated the potential for professional development more positively than those who had moved abroad but were more highly security driven. However, none of these studies compared all three populations of inbounds, outbounds and locals and none incorporated the broad context that the individuals were embedded in. Boundaryless career research is interested in how and why individuals cross borders in relation to e.g. organizations, occupations, physical distance, geographical location and psychological patterns (Sullivan and Baruch, 2009). This makes the assessment of the broader context of the location that expatriates and locals are embedded in highly important. While the macro-context is likely to be important for all expatriates, it seems particularly crucial for SIEs given their higher agency in the location decision (Vaiman and Haslberger, 2013). In so doing it should allow us to refine our picture of expatriation drivers and location attractiveness. Overall, it is likely to nuance our understanding of boundaryless careers.

So far the existing research focuses predominantly on individual and organizational influence factors to work abroad. It does little to illuminate the exact drivers and barriers associated with specific locations and more particularly, with particular cities. Arguably, it matters to individuals whether they are going to Shanghai or into a small city within China. Especially in relation to their professional background and personal interests, it may be key to an individual computer scientist whether the move is to Silicon Valley or a region in Iowa when moving to the USA or to a finance specialist whether s/he would move to London or Newcastle in the UK. 
In contrast, there are surveys within the professional literature that look at city attractiveness (MMF Institute for Urban Strategies 2011; Mercer, 2014). These surveys tend to be focussed on several broad contextual issues - purchasing power, education opportunities, local work regulations, etc. - to the detriment of more individual drivers such as personal drivers and at times, career development considerations. In addition, they concentrate on expatriates without surveying local citizens. Overall, this is another indication of the importance of a holistic picture that uses individual, organizational and macro-contextual perspectives.

There has been little identifiable academic research about individual drivers to work abroad in a specific city but most prominently investigated are London and Vienna for city attractiveness. In Dickmann's (2013) research into why foreign-born individuals go to work in London, career considerations are most important. In addition, location factors such as the reputation of London as a global centre for business, multiculturalism and the desire to live in the British capital, have a strong impact on individuals' willingness to move to London (Dickmann and Mills, 2010). Research conducted in Vienna by Haslberger and Zehetner (2008) has shown that expatriates make a distinction between work and non-work factors when choosing an assignment location. The location-focused professional environment in the respective cities was important in both studies. Given the relative paucity of this line of enquiry, it seems clear that location-specific attraction factors need to be further explored in international mobility research. A superior knowledge base allows us to refine our understanding of global mobility and boundaries in modern careers.

\section{Beyond Individual and Organizational Factors - The Importance of Macro-Factors.}

This literature overview was aimed as eliciting the general factors that are important to attract individuals to work abroad. However, most studies have concentrated on the individual and/or organizational level while $\mathrm{Ng}$ et al., (2007) advise us not to neglect the structural level. It is important to factor in economic conditions, societal and industry differences which have an impact on individuals' willingness to go abroad. These authors gain some support from social geography. Social geographers have measured the relative attractiveness of destinations using macro-factors such as economic context (e.g. unemployment), safety measures (crime) or social indicators (housing) that explain relative migration inflows or outflows (Fotheringham et al., 2000). This would have the ability to explore drivers of inbound, local and outbound individuals. However, their indicators are very general (they normally do not cover organizational nor individual measures) and sometimes omit political 
and legal factors. For research into migration, Al Ariss et al., (2012:95) suggest a promising extension in that their framework includes a multi-level perspective with a focus on individual, organizational, history and macro-context levels.

Our study takes up their call to look at individual, organizational and macro-factors and their interrelationships. We apply their framework not just to migration but also to local citizens who have decided to stay and work at home. In addition, we extend their broad levels to include further elements such as technological attraction and ecological factors. Overall, this results in macro-factors being explored through a PESTEL ${ }^{1}$ analysis with the addition of drivers such as climate, geographical location or size of location. This paper attempts to address the following research question.

What are the key factors that influence the decisions of individuals to live in a particular South East Asian city?

In so doing, we will also explore the differences in these decision-factors comparing foreign nationals working in the city, locals working in the city and locals who have opted to move to another foreign city. Our insights allow us to propose a broad model of individual location choice factors and explore further theoretical and managerial implications.

\section{METHODOLOGY}

Because of the paucity of available evidence on the motives of both domestic and foreign professionals to work and build their careers in the South East Asian city we used qualitative interviews to explore the 'what', 'why' and 'how' of location decisions (Yin, 2003). Given that this study is exploratory, interviews are a suitable methodological approach. The research was sponsored by a ministry of the national government.

The subjects of our research were highly skilled individuals who either held professional, managerial or executive positions or were students. The study captured rich data from three target groups. The first group consisted of foreign individuals who had moved to the city and who we will call INBOUNDS. While the reasons for expatriates to undertake work abroad have been the focus of several studies (Stahl et al., 2002; Tharenou, 2003) this has rarely

\footnotetext{
${ }^{1}$ PESTEL stands for the analysis of Political, Economic, Social, Technological, Ecological and Legal factors. The framework and its use is described in Van Assen et al. (2008).
} 
been researched in relation to a specific location. In addition, almost all research concentrates on INBOUNDS but we have argued above that two further groups would also give us valuable information. Therefore, we interviewed local citizens who were presently living in the city for the second group (LOCALS) and people who had grown up in the city and had decided to work abroad (OUTBOUNDS) as a third group. To our knowledge this is novel in the field of expatriation drivers and boundaryless careers.

The study used non-representative snowball sampling as we were aiming for highly skilled people who ideally had a substantial understanding of other locations and/or a professional opportunity to work elsewhere if they chose to do so. Initial interviewees were found based on contacts from the government, local universities and a large consultancy organization. Fifty individuals living in the South East Asian city were approached for an interview and 188 highly skilled persons in New York, London, Hong Kong and Shanghai. Between April and August 2010 we interviewed 17 INBOUNDS, 14 LOCALS and 12 OUTBOUNDS. All INBOUNDS and LOCALS were interviewed face to face while OUTBOUNDS were interviewed on the phone. Almost all interviewees had substantial experience of living in two or more major cities - only six LOCALS had never lived elsewhere for a longer period. We hoped that this would enable them to be sensitive, reflective and informed about individual, organizational and macro-locational factors. The interviews normally lasted between 45 minutes and two hours. Appendix 1 gives an anonymized overview of the interviewees that shows the high diversity in terms of nationality, gender, industry and foreign experience.

The research pursued an exploratory aim due to the gap in the literature outlined above (Miles and Hubermann 1994). Taking the work of Dickmann and Mills (2010) as a starting point, the interviews explored the individual, organizational and macro-factors of the reasons for living in the South East Asian city or moving away. Appendix 2 presents the relevant part of the interview questionnaire. Through the questions it can be observed that the political, economic, socio-cultural, technological, ecological and legal context is being explored as well as the key international mobility drivers known from the literature presented above. The semi-structured format allowed probing where information was unclear or seemed to be leading to deeper or unusual insights (Yin, 2003). 
The interviews were recorded, minuted and transcribed. We conducted a template analysis as we had such a large number of interviewees (King, 1998) using the following process to increase the quality of the analysis. The transcripts were read, analysed and reviewed through an iterative process by the two researchers and the data was organized by recurrent patterns and structured into analytical themes. We used hierarchical coding with codes distinguishing PESTEL factors, further location factors such as climate, language, history, time zone, career and development drivers (Dickmann and Mills, 2010), organizational factors (Stahl et al., 2002), or partner, family and friendship considerations defined a priori based on the literature and reflected in the interview questionnaire. This is seen as one of the best starting points for constructing an initial template (King, 1998: 122). Any interview statements that were coded differently by the two researchers were discussed using the whole interview transcript. A joint decision as to the coding was possible in all but six cases. These cases showed some overlaps in the categories (career opportunities - individual interest or organizational inducement/individual drivers that coincide with macro-factors such as availability of job opportunities). We refined the categories and approached the original interviewees for clarification.

The analysis below will outline some major factors that attract individuals to work/study in the South East Asian city. Due to the richness of the qualitative research we present in table format the points mentioned by more than $30 \%$ of our interviewees.

\section{FINDINGS}

\section{Attraction to the South East Asian City - Macro-Location Factors}

In a globalized world, attracting the right talent is paramount. In this study we have looked at both foreign citizens attracted to work or study in the South East Asian city and local citizens who either stayed in or returned to the city to pursue their lives. In addition, we have contrasted their views with those individuals who grew up in the city but chose to leave it.

Table 1 gives an overview of the most frequently cited factors that influence the decision to stay in or come to the South East Asian city. City attractiveness data can be analysed using a PESTEL analysis structure and adding wider factors such as language, climate, time zone, history etc. (Al Ariss et al., 2012; Dickmann, 2013). 
Insert Table 1 here

The overall picture of the South East Asian city's attractiveness is positive for the majority of respondents and even for many of those who had worked elsewhere - especially if they lived in Hong Kong or Shanghai. The key factors are outlined below.

\section{Political}

Factors such as the political stability of the host country have been shown to be important for individuals to move to a country (Yurkiewicz and Rosen, 1995). The interviewees overwhelmingly attested the South East Asian city was a highly attractive political environment with efficiency and openness being frequently mentioned by the city dwellers. INBOUNDS appreciated the open regulations with respect to expatriates working in the South East Asian city - on occasion LOCALS asked for job protection from foreign competition.

[The city] has transparent and pragmatic business policies. (David, LOCAL)

Some of the OUTBOUNDS remarked, however, that the city picked 'winning industries' and if you happened to work outside of those then the incentive to move abroad would be high. At times a lack of political openness and 'true democracy' was mentioned - however, this was infrequent and did not reflect the majority of views in any of the groups studied. Overall, these remarks show that it is not simply the visa and employment regulations that are important for the decision to work in the city (Andresen et al., 2012; Dowling et al., 2008) but also wider business politics that have an impact on the willingness to live in this city.

\section{Economic}

The economic environment characterised by steady growth, low unemployment and a high talent base is seen as highly attractive by the respondents. The South East Asian city that our research investigates has a high Gross Domestic Product (per capita) of more than $£ 25,000$ and a low tax regime (the highest personal income tax is $20 \%$ ). While the city is by no means in a unique position it can be regarded as attractive for financial reasons. The South East Asian city has managed, in the mind of the interviewees, to become a regional hub that 
allows a good standard of living and that attracts multinational corporations which, in turn, create employment prospects.

[The city] is a regional hub. You would get a very good job in that region, plus the general lifestyle and the standard of living in [the city] is quite good. (Subhangi, INBOUND)

INBOUNDS stated frequently that affordable housing and the availability of skilled resources was a key attraction factor. OUTBOUNDS in London and NY stated that 'their' arts sector had more attractive employment opportunities than the city of their origin. Overall, all respondents agreed that the city had experienced rapid growth over time. This extends our insights from the international mobility literature in that they perceived that this increased the attractiveness of the location, not just a single employer (Stahl et al., 2002; Hippler, 2009).

\section{Socio-Cultural}

This was an area that respondents commented a lot about. The interviewees overall regarded the socio-cultural environment as attractive. Frequently mentioned were meritocracy, multiculturalism, safety, convenience and quality of life and learning focus, which were all regarded as positive factors in the decision to live in the city. The city's universities were seen as providing high quality education. Although the city has a relatively high Gini coefficient, this was not mentioned by a single interviewee.

Looking at the different target groups indicated that those who had experienced major other cities - i.e. the INBOUNDS and OUTBOUNDS abroad - would like the South East Asian city to be more vibrant. Moreover, INBOUNDS mentioned ease of living, high quality of life, multi-culturalism and the friendliness of people more than domestic citizens. Other research has shown that this is important in the relocation decision and the adjustment of individuals (Yurkiewicz and Rosen, 1995; Toh and DeNisi, 2007).

If you want somewhere that is going to be chilled and you'll have a genuinely nice life and everybody will be friendly and you'll get great food and the beach will be five minutes away, the [city] is the place for you. (Kate, INBOUND) 
Even OUTBOUNDS agreed that the South East Asian city had better housing and friendlier people than New York, London, Hong Kong or Shanghai. They did, however, feel that out of the box thinking was stifled in the city.

[The city] does little to encourage free thinking... In fact, it seems it is change averse. (Lisa, OUTBOUND)

The socio-cultural reasons for them to have moved abroad were highly diverse and linked to the specific location they were working in. For instance, London was seen as great for networking in pubs or NY was valued for the acceptance of expatriates.

Research on international moves has frequently explored how assignees adjust emotionally and intellectually to a different cultural environment (Bhaskar-Shrinivas et al., 2005; Black et al., 1992). The findings point to the importance of host culture, personal security, intercultural sensitivity and language compatibility. In turn, only recently has an interest arisen as to the role which cities and their specific context play in the decision to work abroad. Again, socio-cultural factors can nuance our understanding of boundaryless careers.

\section{Technological}

The assessment of the technology context varied amongst the respondents with some seeing the city only as low to moderately attractive in terms of leading-edge developments. Several of the respondents believed that key technological developments were happening in the USA first. A majority of the OUTBOUNDS thought that successful technology start-ups were easier to achieve in a range of countries outside the city (e.g. USA but also UK).

Everybody thinks of Silicon Valley as at the forefront of tech innovation. [City] lags behind. (William, OUTBOUND)

However, people working in the city often argued that technology would be advanced in 'hub industries' and that these industries would benefit substantially from the administration's support.

It is here where my best career chances are - not anywhere else (Yi, LOCAL) 
INBOUNDS saw the city as the wealth management hub of Asia. However, OUTBOUNDS argued that often other markets such as New York, London or Hong Kong were overall bigger financial markets. The role of technological factors, including industry clusters with particular strengths, is important in the decision to work in a particular location. This hub idea would create a potential career stickiness, creating non-regulatory, location-specific (but not organizational) barriers to careers.

\section{Ecological}

All interviewees agreed that the city is clean and most mentioned the high air quality. This was universally seen as attractive and sometimes seen as an advantage with respect to raising a family. One respondent said:

This is Switzerland in Asia..... It is important for me that my children can play outside (Arjen, INBOUND).

Ecological factors are rarely factored into the analysis of international mobility and even broad frameworks such as that by Al Ariss et al., (2012) omit these. It gives a useful nuance to boundaryless career ideas.

Legal

Most respondents who lived in the city appreciated the clear laws and transparent regulations. The expatriates argued that this especially made life so much easier than in other places they had lived in. If this knowledge is easily accessible for everyone then this would presumably be a higher incentive to go to the city than to other locations where the legal and regulatory framework is less stable and accessible.

I don't really mean the visa and work permit issues: my company did this for me. I mean the ease of living your daily life here. In Russia - and even in Thailand - I found it much more complicated and too frequently shifting. (Samsuk, INBOUND).

However, some OUTBOUNDS disagreed. Especially people in Hong Kong argued that the city was a 'well-oiled machine' and that the regulations impacting day-to-day work would be less strenuous. Most research on global boundaryless careers concentrates on legal 
regulations with respect to entry visas, residence and working permits (Dowling et al., 2008; Al Ariss et al., 2012). Our research shows that regulatory issues that affect the day-to-day living in a foreign location should also be incorporated in the factors that influence boundaryless careers.

\section{Natural and General City Factors}

There is a number of wider city or Asian factors that were mentioned by the interviewees as having an impact on their decision about where they lived. Language, travel and mobility and the geographical location in Asia (within a high development region) were appreciated by LOCALS and INBOUNDS. English is widely used as the language of business and was seen as a key attraction factor by INBOUNDS who perceived that they could express themselves better and would be more effective in business.

The South East Asian city is at the heart of Asian developments and was quoted frequently by LOCALS and sometimes by INBOUNDS.

[City] is one of the undisputed centres of Asia. It is successful. What attracts me to it is its leadership position within Asia (Michelle, LOCAL).

The weather in the city was seen as better than in New York or London by OUTBOUNDS. Those who had lived abroad also appreciated the compactness of the South East Asian city as it gave greater access to important people and made city-wide travel easier. Again, we find that the detail in the description allows us to extend the list of macro-factors that can impact on boundaryless career decisions. We will now discuss individual and organizational factors that had an impact on our interviewees' location decisions.

\section{Attraction to the South East Asian City - Organizational and Individual Factors}

The literature has shown that beyond the specific PESTEL attractiveness factors, individuals evaluate a host of other variables when deciding where to live, work or study. Above we have categorized these as company and job, organizational inducement, personal drivers, career and development and family and partner considerations. While overlaps between these categories exist, the first two factors are more employer-related while the last three are more individual-related. To understand what drives individuals to live in the city or to leave it, 
these decision factors also have to be taken into account. Table 2 provides an overview of the findings.

Insert Table 2 here

\section{Company and Job/Study Factors}

Overall, work and study opportunities are seen as attractive due to the high quality of education, availability of work positions, meritocracy within organizations that are located in the South East Asian city and the business development of the region. LOCALS felt especially attracted by the meritocracy at work and job opportunities.

\section{And I just thought I didn't want to miss the transformation of [the city]. Because it was clear that [the South East Asian city] was going to do a step jump to the next level which it did. ...and that would give me great job opportunities. (Cheng, LOCAL)}

As it is clear from the general career literature, the specific nature of the job was also highly important for individuals. INBOUNDS felt attracted by the nature of the job opportunities, especially those associated with work with major clients and broad learning opportunities. OUTBOUNDS did not question that the city gave good job opportunities. However, their companies had often provided the chance to move abroad and progress in their careers through expatriate work. In essence, all OUTBOUNDS valued their company's career opportunities. Some thought that Hong Kong and Shanghai have better career opportunities in their organization and working in New York would be highly beneficial for general career progression.

Organizational Inducements: The overarching trends shared between all the interviewee groups were that organizational inducements had a positive impact on their location decisions and that they valued the global business experience that their current location could give them. The nature of the inducements, however, could vary substantially. 
I came here because I got a scholarship from [a city organization] in [city]. (Phone, INBOUND)

Analysing the target groups more closely, the following patterns emerged. Working in global entities is highly attractive to LOCALS. In addition, LOCALS appreciated the chance to work in the (regional) head offices of corporations. In turn, INBOUNDS felt attracted to the city if the Asian network of the corporation was extensive.

\section{Career and Development Factors}

Career opportunities in the city were seen as highly positive by LOCALS and INBOUNDS. LOCALS especially valued their ability to work with diverse people in the South East Asian city whereas INBOUNDS appreciated the possibility to gain valuable Asia experience and pointed out the regional career opportunities. Many INBOUNDS argued that the high quality education and work experienced to be gained in the city would result in good job prospects.

So, [the city] is much more developed and once you study here you are likely to get a good job. And then, a few years later, you can go home and you have super career prospects. (Cherry, INBOUND)

LOCALS valued the career development inherent in working with professionals from diverse backgrounds and nationalities.

For what I do, [the city] is considered a hub. So, a lot of the major players are, actually, based here. From a networking perspective, it helps a lot from a clientfacing perspective. And that is good for my career. (Lee, LOCAL)

The OUTBOUNDS raised a few interesting issues. First, many argued that international experience is important in their industries. This is a point that reiterates the value of global career research. Second, other cities such as New York and London also offered them major learning opportunities. Third, LOCALS and OUTBOUNDS sometimes argued that highly skilled female employees would experience better careers in Western multinationals in the three Asian cities under investigation. In addition female interviewees often felt highly pressured and related this to societal expectations with regards to gender roles, childcare, 
children's education and household chores in the three Asian cities. This was not the focus of the current study but further exploration could possibly be a worthy academic contribution.

While it is sometimes difficult to distinguish between actual job, organization and city location, it seems that the South East Asian city's policy to foster university education and specific industries has resulted in several of these becoming Asian 'hubs'. This has led to LOCALS and INBOUNDS increasing their own human capital and, at times, the perceived boundaryless of their own careers. The impact of city locations on boundaryless career opportunities has not been sufficiently explored in the extant literature.

\section{Partners, Family and Friendship Considerations}

Almost all interviewees pointed out that the city had a great environment for families in terms of the above discussed macro-factors of education, child-friendliness, safety and healthy environment. While a few LOCALS and INBOUNDS referred to the pressures and high stress levels associated with education in the city - both for children as well as for mothers they nevertheless commented positively about the education system and saw this as an attraction factor. Most LOCALS valued the proximity to the extended family and their friends. In contrast to INBOUNDS, some locals commented on the convenience to "come home' and on feeling an obligation to be near their family and/or to respect the wishes of their family to return to their city.

After studying and working for two years in London ... wanting to go home in respect for my parents' wishes. (Gary, LOCAL)

Many of the OUTBOUNDS agreed that in their city of origin it was more affordable to bring up a family. Only London was seen as giving better work-life balance.

\section{Personal Drivers}

As the reader would expect, personal drivers to live in the South East Asian city vary widely. Amongst the more prominent motives for INBOUNDS from Western (developed) countries were the wish to live in Asia and to be involved in the development of a region "where the future lies'. 
And I always wanted to go to Asia, to experience it. It was always a dream and then I thought to myself, let's make it happen. (Alan, INBOUND).

The wish to experience Asia from a secure base was highly important to professional INBOUNDS while education and within it, the quality, rankings and range of educational provision, is a key personal driver that attracts studying INBOUNDS to the South East Asian city. The OUTBOUNDS generally agreed with the city having some leading universities but argued that New York and London had better business schools.

This paper has now presented the individual, organizational and macro-factors that influence the decision to live in a specific South East Asian city. The next section will summarize the results and draw up implications and conclusions.

\section{DISCUSSION AND CONCLUSIONS}

The study set out to identify the key factors that influence the decisions of individuals to live in a location, in our case in a specific South East Asian city. 43 interviews with highly skilled people who had either moved to the city from abroad (INBOUNDS), had stayed in the city (LOCALS) or had moved abroad (OUTBOUNDS) showed the following picture of their reasons.

Organizational attraction factors in the city location included good job opportunities, learning on the job, global business exposure and practiced meritocracy especially in the many Western multinationals in the city. OUTBOUNDS did, however, point out that other major cities also provided these advantages with New York and London gaining positive comments regarding the acquisition of transferable experience and learning opportunities. All three groups praised the city for its good education, environmental quality and described it as a good location to bring up a family. In addition, LOCALS valued the proximity to their family and friends, INBOUNDS their ability to gain valuable Asia experience and for OUTBOUNDS the relatively low costs vis-à-vis where they were living at the time of the interviews. Some more critical, location-specific observations of the OUTBOUNDS can be seen in Table 2. The individual drivers often had a strong link to broader contextual factors.

With respect to macro-contextual factors, a relatively consistent impression emerged of a city that was valued by all groups due to its efficient governance, employment opportunities, low 
tax rates, meritocracy, safety, friendliness, learning orientation, good ecological management, clear and transparent regulations (Table 1). In addition, LOCALS valued the convenience of the city and INBOUNDS appreciated its openness to foreign talent while seeing it as lacking in vibrancy. OUTBOUNDS compared their location - New York, London, Hong Kong or Shanghai - with the city and while they normally agreed to the above they perceived that 'out of the box thinking' was stifled and that the city's approach to pick industrial winners would disadvantage other industries.

\section{Empirical and Managerial Contribution}

Above, we have outlined some of the key factors that influence the decisions of individuals to live in a particular South East Asian city. This has led to a range of empirical and managerial contributions. First, our research responded to the calls to conduct more location-specific research in international mobility (Dickmann and Mills, 2010; Haslberger and Zehetner, 2008) going beyond cities such as London and Vienna. A particular strength of our contextsensitive approach is that we are able to assess geographical boundaryless career drivers of INBOUND, LOCAL and OUTBOUND individuals. Eliciting careerists views from these three perspectives has been hitherto neglected and results in a more holistic picture of international boundaryless career drivers. In so doing, we overcome some of the inherent weaknesses of other global career research that often does not compare with a nonexpatriated peer group (Doherty et al., 2010).

A second, empirical contribution is that we have gathered a more nuanced and detailed picture of location drivers than is hitherto available. Our data shows that a location can have a relatively clear and consistent image in the minds of people. Research in boundaryless, global careers has tended to focus on individual drivers and organizational inducements (Brookfield, 2012; Stahl et al., 2002). Where writers have covered macro-factors they tended to focus on legal and regulatory barriers to enter a country, work permits and social security issues (Dowling et al., 2008; Andresen et al., 2012). But what mattered to our respondents went beyond that -including more day-to-day aspects of bringing up a family, a healthy ecological environment, the ability to be creative and to think out of the box, the friendliness of domestic citizens or the legal transparency and stability. While some of these factors have been suggested before (e.g. friendliness by Yurkiewicz and Rosen, 1995) they have often not been systematically researched and have rarely been investigated in relation to specific 
locations. These factors, however, do matter to careerists and they can either increase or decrease their psychological or physical career boundaries (Sullivan and Baruch, 2009).

Our findings in respect to the specific drivers of INBOUNDS, LOCALS and OUTBOUNDS give rise to a third, managerial, contribution. While legal career barriers to work internationally may diminish, cities seem to work on increasing their attractiveness (MMF Institute for Urban Strategies, 2011) and, thereby, creating psychological, regulatory, network-based and cultural links that may serve as geographical boundaries to careers. Interestingly, these boundaries go beyond the traditional kind - people in the city administration do not seem to mind staff moving between employers as long as they stay in the South East Asian city. City attraction factors can refine our insights in relation to modern careers and their boundaries. While legal entry boundaries into countries are often reciprocal the city attractiveness factors seemed to work in a different way. Factors such as low unemployment or a secure environment would increase the location attractiveness for expatriates, especially SIEs, while increasing the 'stickiness' for people living locally. Understanding these attraction factors in depth allows organizations to refine their talent sourcing, performance management and retention strategies and gives location advantages to specific cities. Further research to deepen our insights and to extend them to other major cities would be welcome.

\section{Theoretical Contribution}

Most research has attempted to understand attraction, resourcing, talent management or career implications from the perspectives of individuals and organizations (Scullion and Collings, 2011). Al Ariss et al.'s, (2012) work is noteworthy as it goes beyond this predominant perspective to suggest some macro-contextual and historical factors. Our primary theoretical contribution is that our data indicates that further dimensions - sociocultural, technological, ecological - to their macro-factors need to be incorporated in the analysis of international mobility and boundaryless careers. Based on our findings we propose a framework of the broad categories to investigate in global careers and location decisions. It is schematically depicted in Figure 1.

Insert Figure 1 here 
Figure 1 is based on the approach of Dickmann and Mills (2011) who depict international location choices and modern global careers as an interaction of individual and organizational interests, attitudes, behaviours and incentives. Our framework broadens their ideas to incorporate the macro-factor argument of Al Ariss et al., (2012). Moving beyond a pure migration setting, it depicts wider contextual factors in specific location choice. In addition, Figure 1 outlines more broad categories than Al Ariss et al., (2012) in that it adds political, socio-cultural, ecological and natural-general factors. Our study has shown that these and other PESTEL factors have a bearing on the choice of individuals as to where they want to live. In addition, Figure 1 depicts a framework that can be used both to understand international and domestic location and work choices, thereby adding to modern boundaryless career insights.

Using these factors helps us to understand boundaryless career influences better. It is reasonable to suggest that the macro-contextual level may be particularly important to SIEs given their broader, more holistic drivers (Doherty et al., 2011; Thorn, 2009; Carr et al, 2005). The framework could also be used to formulate a multitude of propositions in the area of boundaryless global careers. We only suggest a few propositions that are related to the areas in which our study goes beyond the Al Ariss et al (2012) conceptualisation.

Political. In the management and academic literature the argument is well rehearsed that organizations like to locate in countries/cities in which they find a stable and efficient regulatory framework that is open to foreign investment (Dowling et al., 2008). However, our data indicates that these qualities are also appreciated by individuals, especially for SIEs who partially based location decision on "openness to foreign individuals".

P1. An open, stable and efficient government is a significant and positive attraction factor for expatriates in their location decisions.

'Efficiency' can be gauged through an estimate of cost and effort in obtaining legal permits to move to the location, the right to work and stay. In addition, the feeling of non-discrimination and opportunities for expatriates is likely to be especially important to SIEs. 
Socio-cultural. There is no doubt that the socio-cultural context is important to people wherever they live. While many aspects have been covered through a wide range of media, the academic research has concentrated on factors such as quality of life, host population hospitality and friendliness, cosmopolitarianism and purchasing power parity (Mäkelä and Suutari, 2013; Dowling et al., 2008). Less explored are a range of issues outlined below:

P2. A socio-cultural environment that values meritocracy, is safe, vibrant, allows a good work-life balance and has high standard, affordable housing is a significant and positive attraction factor for expatriates in their location decisions.

The point here is not that these factors are new or surprising; it is that these were valued so highly by the respondents and that they are less systematically explored in the academic literature. Especially, meritocracy seems to be hitherto neglected and could provide an exciting research avenue with respect to career patterns.

Natural-general. Climate factors, time zone implications and language have been explored in extant research (Yurkiewicz and Rosen, 1995; Dickmann, 2013). However, the compactness of a location that would allow access to more senior people and provide networking opportunities or the convenience of living have been less explored.

P3. A compact location that enables networking, easy travel within the location and convenience are significant and positive attraction factors for expatriates in their location decisions.

While many of the key influencing factors have already been researched, the above propositions aim to show that there are still many neglected expatriation drivers (and motivators for locals to stay) that influence boundaryless career decisions. It would be easy to draw up a large range of further propositions. However, the key argument is not to get lost in ever smaller detail but to make a conscious decision to develop a broad view of boundaryless global career decisions that factors in the macro-context of specific locations.

The limitations of qualitative research studies are well known and apply principally to the issue of generalizability. While there is always a risk that interviewees give socially acceptable answers, we believe that the guaranteeing of anonymity and the origin of the 
researchers from two non-domestic universities will have reduced this effect. The sampling was non-random and favoured individuals who had lived in at least two major cities, ideally in two different countries. In addition, we concentrated on highly skilled individuals, either at university or in a middle or senior role in their organizations. While this approach reduces the representativeness of our findings it was likely to lead to interviewees who had first-hand experience in location choices and the complex analysis of many contextual, organizational and individual factors. While we believe that this has given us better insights into the location attractiveness factors it means that we cannot generalize to the wider population, especially where individuals have a low skills base. Instead, it allows us to understand how a city may be perceived by highly skilled persons. Most city administrators want to attract these 'high potentials' in the global competition for talent.

In a globalized world it would be fascinating to understand the attractiveness of a range of major cities and, additionally, the career experiences of individuals living in them. We believe it is time to combine the individual, organizational and macro-contextual city perspectives to explore location choices and modern career patterns in more depth. 


\section{BIBLIOGRAPHY}

Al Ariss, A., Koall, I., Özbilgin, M. and Suutari, V. (2012), "Careers of skilled migrants: Towards a theoretical and methodological expansion", Journal of Management Development, Vol. 31, No. 2, pp. 92-101.

Andresen, M., Al Ariss, A. and Walther, M. (2012), Self-initiated expatriation: individual, organizational and national perspectives, (edited book), Routledge, London.

Arthur, M.B., Khapova, S.N., and Wilderom, C.P.M. (2005), "Career success in a boundaryless career world", Journal of Organizational Behavior, Vol. 26, No. 2, pp. 177202.

Arthur, M.B., and Rousseau, D.M. (1996), "A career lexicon for the 21st century", The Academy of Management Executive, Vol. 10, No. 4, pp. 28-29.

Baruch, Y. (2004). Managing Careers: Theory and Practice, FT Prentice Hall, London.

Bhaskar-Shrinivas, P., Harrison, D., Shaffer, M. and Luk, D. (2005), "Input-based and timebased models of international adjustment: meta-analytic evidence and theoretical extensions", Academy of Management Journal, Vol. 48, No. 2, pp. 257-281.

Biemann, T. and Andresen, M. (2010), "Self-initiated foreign work experience versus expatriate assignment: A distinct group of international careerists?", Journal of Managerial Psychology, Vol. 25, pp. $430-448$.

Bird, A. and Osland, J. (2004), "Global competencies: an introduction", in Lane, H.W., Maxnewski, M.L., Mendenhall, M.E. and McNett, J. (Eds), Handbook of Global Management, Blackwell Publishing, Oxford.

Black, J.S., Gregersen, H.B. and Mendenhall, M.E. (1992), Global Assignments: Successfully Expatriating and Repatriating International Managers, Jossey-Bass, San Francisco, CA. 
Brett, J. and Stroh, L. (1995), "Willingness to relocate internationally", Human Resource Management, Vol. 34, No. 3, pp. 405-424.

Brookfield Global Relocation Survey (2012), Global Relocation Trends: 2012 Survey Report, Woodridge, Illinois, USA.

Caligiuri, P. (2012), Cultural Agility: Building a Pipeline of Successful Global Professionals, Jossey-Bass, San-Francisco, CA.

Carr, S.C., Inkson, K., and Thorn, K. (2005), "From global careers to talent flow: Reinterpreting ‘brain drain””, Journal of World Business, Vol. 40, No. 4, pp. 386-398.

Cerdin, J-L. (2008), “Careers and expatriation”, in Dickmann, M., Brewster, C. and Sparrow, P. (Eds), International Human Resource Management: A European Perspective, Routledge, Abingdon.

Cerdin, J-L. (2012), "Motivation of self-initiated expatriates", in Andresen, M., Al Ariss, A. and Walther, M. (Eds), Self-initiated expatriation: individual, organizational and national perspectives, Routledge, London.

Cerdin, J-L., and Le Pargneux, M. (2010), 'Career anchors: a comparison between organization-assigned and self-initiated expatriates,' Thunderbird International Business Review, Vol. 52, No. 4, pp. 287-299.

Cerdin, J-L., and Selmer, J. (2014), "Who is a Self-Initiated Expatriate? Towards conceptual clarity of a common notion”. International Journal of Human Resource Management, Vol. 25, No. 9, pp.1281-1301.

Dickmann, M. (2013), "Why do they come to London? Exploring the Motivations of Expatriates to Work in the British Capital", Journal of Management Development, Vol. 31, No. 8, pp. 783-800. 
Dickmann, M. and Mills, T. (2010), "The importance of intelligent career and location considerations: exploring the decision to go to London", Personnel Review, Vol. 39, No. 1, pp. 116-134.

Dickmann, M., Doherty, N., Mills, T. and Brewster, C. (2008), "Why do they go? Individual and corporate perspectives on the factors influencing the decision to accept an international assignment", International Journal of Human Resource Management, Vol. 19, No. 4, pp. 731-751.

Doherty, N., Dickmann, M. and Mills, T. (2010), "Mobility attitudes and behaviours among young Europeans”, Career Development International, Vol. 15, No. 4, pp. 378-400.

Doherty, N., Dickmann, M. and Mills, T. (2011), "Exploring the Motives of CompanyBacked and Self-Initiated Expatriates", The International Journal of Human Resource Management, Vol. 22, No. 3, pp. 595-611

Dowling, P., Festing, M. and Engle, A. (2008), International Human Resource Management. $5^{\text {th }}$ Edition, Thomson, London.

Fotheringham, A.S., Champion, T., Wymer, C. and Coombes, M. (2000), "Measuring Destination Attractivity: A Migration Example", International Journal of Population Geography, Vol. 6, pp. 391-421.

Granrose, C.S. and Baccili, P.A. (2006), "Do psychological contracts include boundaryless or protean careers?", Career Development International, Vol. 11, pp. 163-182.

Gregersen, H.B., Morrison, A.J. and Black, J.S. (1998), "Developing leaders for the global frontier", Sloan Management Review, Vol. 40, No. 1, pp. 21-33.

Gunz, H., Peiperl, M. and Tzabbar, D. (2007), "Boundaries in the Study of Careers", in H. Gunz and M. Peiperl, (Eds), Handbook of Career Studies, Sage, Thousand Oaks, pp. 471493. 
Hall, D.T. (1976), Careers in Organizations, Goodyear Publishing Co., Pacific Palisades, CA, USA.

Hall, D.T. (1996), "Protean careers of the 21st century", The Academy of Management Executive, Vol. 10, No. 4, pp. 8-16.

Harvey, M. (1995), “The impact of dual-career families on international relocations", Human Resource Management Review, Vol. 5, pp. 223-44.

Haslberger, A. and Zehetner, K. (2008), "Cosmopolitan appeal: what makes a city attractive to expatriates and how do they benefit? The example of Vienna, Austria", in $4^{\text {th }}$ Workshop on Expatriation, October 2008, EIASM, Las Palmas de Gran Canarias, Spain.

Hippler, T. (2009), "Why do they go? Empirical evidence of employees' motives for seeking or accepting relocation", The International Journal of Human Resource Management, Vol. 20, No. 6, pp. 1381-1401.

Inkson, K., Arthur, M.B., Pringle, J. and Barry, S. (1997), "Expatriate assignment versus overseas experience: contrasting models of international human resource development", Journal of World Business, Vol. 32, No. 4, pp. 351-368.

Inkson, K, and Myers, B. (2003), ““The big OE”: self-directed travel and career development", Career Development International, Vol. 8, Iss. 4, pp.170 - 181.

Jokinen, T., Brewster, C., and Suutari, V. (2008), "Career capital during international work experiences: contrasting self-initiated expatriate experiences with assigned expatriation", The International Journal of Human Resource Management, Vol. 19, No. 6, pp. 979-998.

King, N. (1998), "Template Analysis", in Symon, G. and Cassell, C. (Eds), Qualitative Methods and Analysis in Organizational Research, A Practical Guide, Sage, London, pp. 118-134. 
Lazarova, M. and Cerdin, J.L. (2007), "Revisiting repatriation concerns: Organizational support vs. career and contextual influences", Journal of International Business Studies, Vol. 38, No. 3, pp. 404-429.

Linehan, M. and Walsh, J. (2000), "Work-family conflict and the senior female international", British Journal of Management, Vol. 11, No. S1, pp. S49-S58.

Mäkelä, L. and Suutari, V. (2013), "The work-life interface of self-initiated expatriates: Conflicts and enrichment", in Vaiman, V. and Haslberger, A., (Eds) Managing Talent of Self-initiated Expatriates: A neglected source of the global talent flow, Palgrave MacMillan, London, pp. 278-303

Mayrhofer, W., Iellatchitch, A., Meyer, M., Steyrer, J., Schiffinger, M. and Strunk, G. (2004), "Going beyond the individual. Some potential contributions from a career field and habitus perspective for global career research and practice", Journal of Management Development, Vol. 23, No. 9, pp. 870-884.

Mellahi, K. and Collings, D. (2010), "The barriers to effective global talent management: The example of corporate élites in MNEs", Journal of World Business, Vol. 45, No. 2, pp. 143 149.

Mendenhall, M. (2001), "New perspectives on expatriate adjustment and its relationship to global leadership development”, in Mendenhall, M., Kühlmann, T. and Stahl, G. (Eds), Developing Global Business Leaders, Quorum, Westport.

Mercer (2014). "Quality of living city rankings". available at http://www.mercer.com/qualityofliving; (accessed on 19. Feb. 2014).

Miles, M.B., and Huberman, A.M. (1994), Qualitative Data Analysis, (2nd ed), Sage, Thousand Oaks, CA, USA.

MMF Institute for Urban Strategies, The Mori Memorial Foundation, (2011), "Global Power City Index 2011", available at:

http://www.mori-m-foundation.or.jp/english/research/project/6/pdf/GPCI2011_English.pdf 
(accessed 03. Dec 2011).

Ng, T.W.H., Sorensen, K.L., Eby, L.T., and Feldman, D.C. (2007), “Determinants of job mobility: A theoretical integration and extension", Journal of Occupational and Organizational Psychology, Vol. 80, No. 3, pp. 363-386.

Oberholster, A., Clarke, R., Bendixen, M., and Dastoor, B. (2013), "Expatriate motivation in religious and humanitarian non-profit organizations", Journal of Global Mobility, Vol. 1, No. 1, pp. 7-27.

Peiperl, M. and Jonsen, K. (2007), "Global careers", in Gunz, H. and Peiperl, M. (Eds), Handbook of Career Studies, Sage, Thousand Oaks.

Peltokorpi, V. (2008), "Cross-cultural adjustment of expatriates in Japan", The International Journal of Human Resource Management, Vol. 19, No. 9, pp. 1588-1606.

Peltokorpi, V., and Froese, V. (2009), "Organizational expatriates and self-initiated expatriates", International Journal of Human Resource Management, Vol. 20, No. 5, pp. 1096-1112.

Richardson, J. (2006), “Self-directed expatriation: family matters", Personnel Review, Vol. 35, No. 4, pp. 469-486.

Richardson, J. and Mallon, M. (2005), "Careers interrupted? The case of the self-directed expatriate", Journal of World Business, Vol. 40, No. 4, pp. 409-420.

Scullion, H. and Collings, D. (2011), Global Talent Management (edited book), Routledge, London.

Shaffer, M.A., Kraimer, M.L., Chen, Y.P., and Bolino, M.C. (2012), "Choices, challenges, and career consequences of global work experiences: A review and future agenda", Journal of Management, Vol. 37, No. 4, pp. 1282-1327.

Sparrow, P., Brewster, C. and Harris, H. (2004), Globalizing Human Resource Management, Routledge, London. 
Stahl, G. and Cerdin, J.L. (2004), "Global careers in French and German multinational corporations", Journal of Management Development, Vol. 23, No. 9, pp. 885-902.

Stahl, G.K., Miller, E. and Tung, R. (2002), "Towards the boundaryless career: a closer look at the expatriate career concept and the perceived implications of an international assignment", Journal of World Business, Vol. 37, No. No. 3, pp. 216-227.

Sullivan, S.E., and Arthur, M. (2006), "The evolution of the boundaryless career concept: Examining physical and psychological mobility”, Journal of Vocational Behavior, Vol. 69, No. 1, pp. 19-29.

Sullivan, S.E. and Baruch, Y. (2009), "Advances in career theory and research: A critical review and agenda for future exploration", Journal of Management, Vol. 35, No. 6, pp. 1542-1571.

Suutari, V. and Brewster, C. (2000), "Making their own way: international experience through self-initiated foreign assignments", Journal of World Business, Vol. 35, No. 4, pp. 417-436.

Tarique, I. and Schuler, R. (2010), "Global talent management: Literature review, integrative framework, and suggestions for further research", Journal of World Business, Vol. 45, No. 2, pp. 122-133.

Tharenou, P. (2003), “The initial development of receptivity to working abroad: self-initiated international work opportunities in young graduate employees", Journal of Occupational and Organizational Psychology, Vol. 76, No. 4, pp. 489-515.

Tharenou, P. (2010), "Women's self-initiated expatriation as a career option and its ethical issues", Journal of Business Ethics, Vol. 95, No. 1, pp. 73-88.

Tharenou, P. and Caulfield, N. (2010), "Will I stay or will I go? Explaining repatriation by self-initiated expatriates". Academy of Management Journal, Vol. 53, No. 5, pp. 10091028. 
Thorn, K. (2009), "The relative importance of motives for international self-initiated mobility", Career Development International, Vol. 14, No. 5, pp. 441 - 464.

Tung, R.L. (1998), "American expatriates abroad: From neophytes to cosmopolitans", Journal of World Business, Vol. 33, No. 2, pp. 125-144.

Toh, S.M. and DeNisi, A.S. (2007), "Host country nationals as socializing agents: a social identity approach", Journal of Organizational Behavior, Vol. 28, No. 3, pp. 281-301.

Vaiman, V. and Haslberger, A. (2013). Managing Talent of Self-initiated Expatriates: A neglected source of the global talent flow. (edited book), Palgrave MacMillan, London.

Van Assen, M., Van Den Berg, G. and Pietersma, P. (2008), Key Management Models: The $60+$ models every manager needs to know, FT Prentice Hall, London.

Vance, C. (2005), “The personal quest for building global competence: a taxonomy for selfinitiating career path strategies for gaining business experience abroad", Journal of World Business, Vol. 40, No. 4, pp. 374-385.

Yan, A., Zhu, G. and Hall, D. (2002), "International Assignments for Career Building, a Model of Agency Relationships and Psychological Contracts", Academy of Management Review, Vol. 27, No. 3, pp. 373-391.

Yin, R. K. (2003), Case Study Research Design and Methods, Sage Publications, London.

Yurkiewicz, J. and Rosen, B. (1995), "Increasing receptivity to expatriate assignments", in J. Selmer, J. (Ed), Expatriate Management, Quorum, Westport. 